\title{
A comparative study of post-operative astigmatism in superior versus superotemporal scleral incisions in manual small incision cataract surgery in a tertiary care hospital
}

\author{
Soumyadeep Hazra** and Tapes Kanti Saha ${ }^{2}$ \\ 'Senior Resident, Jagannath Gupta Institute of Medical Sciences and Hospital, Budge Budge, \\ Kolkata, West Bengal, India \\ ${ }^{2}$ Assistant Professor, Jagannath Gupta Institute of Medical Sciences and Hospital, Budge Budge, \\ Kolkata, West Bengal, India
}

\section{Abstract}

Background: In developing countries, manual small incision cataract surgery is a better alternative and less expensive in comparison to phacoemulsification and thus the incision is an important factor causing high rates of postoperative astigmatism resulting into poor visual outcome. Thus, modifications to the site of the incision is needed to reduce the pre-existing astigmatism and also to prevent postoperative astigmatism. Modification to superotemporal incision relieves pre-existing astigmatism majorly due to its characteristic of neutralizing against-the-rule astigmatism, which is more prevalent among elderly population and thus improves the visual outcome.

Aims: To study the incidence, amount and type of surgically induced astigmatism in superior and superotemporal scleral incision in manual SICS.

Methodology: It is a randomized, comparative clinical study done on 100 patients attending the OPD of Ophthalmology at a tertiary care hospital, with senile cataract within a period of one year and underwent manual SICS. 50 of them chosen randomly for superior incision and rest 50 with superotemporal incision. MSICS with PCIOL implantation were performed through unsutured $6.5 \mathrm{~mm}$ scleral incision in all. Patients were examined post-operatively on $1^{\text {st }}$ day, $7^{\text {th }}$ day, $2^{\text {nd }}$ week and $4^{\text {th }}$ week and astigmatism was evaluated and compared in both groups.

Results: It is seen that on postoperative follow up on 4th week, $77.78 \%$ of the patients with ATR astigmatism who underwent superior incision had increased astigmatism whereas, only $13.63 \%$ of the patients with ATR astigmatism who underwent supero-temporal incision, had increased astigmatism but $81.82 \%$ had decreased ATR astigmatism. However, $77.78 \%$ of the patients with preoperative WTR astigmatism who underwent supero-temporal incision, had increased astigmatism, whereas $44.45 \%$ of the patients with WTR astigmatism preoperatively, had increased astigmatism in contrast to $50 \%$ had decreased amount of astigmatism. It is also seen that the supero-temporal incision group had more number of patients $(78 \%)$ with visual acuity better than $6 / 9$ at $4^{\text {th }}$ postoperative week than superior incision group ( $\left.42 \%\right)$.

Conclusion: This study concludes that superior incision cause more ATR astigmatism postoperatively whereas superotemporal incision causes lower magnitude of WTR astigmatism, which is advantageous for the elderly. Besides superotemporal incision provides better and early visual acuity postoperatively.

\section{Introduction}

Astigmatism is a condition in which a point of light is not formed on retina which occurs when toricity of any of the refractive surfaces of the optical system produces two principal foci delimiting an area of intermediate focus called "conoid of sturm" [1]. Astigmatism induces distortion of

\section{More Information}

*Address for Correspondence:

Dr. Soumyadeep Hazra, Senior Resident, Jagannath Gupta Institute of Medical Sciences and Hospital, Budge Budge, Kolkata, West Bengal, India, soumyadeep.hazra@gmail.com

Submitted: July 21, 2021

Approved: August 04, 2021

Published: August 05, 2021

How to cite this article: Hazra S, Saha TK. A comparative study of post-operative astigmatism in superior versus superotemporal scleral incisions in manual small incision cataract surgery in a tertiary care hospital. Int J Clin Exp Ophthalmol. 2021; 5: 009-015.

DOI: 10.29328/journal.ijceo.1001036

Copyright: @ 2021 Hazra S, et al. This is an open access article distributed under the Creative Commons Attribution License, which permits unrestricted use, distribution, and reproduction in any medium, provided the original work is properly cited.

Keywords: MSICS; ATR astigmatism; WTR astigmatism; Surgically induced astigmatism; Superotemporal incision; Superior incision

\section{Check for updates}

OPEN ACCESS 
is one in which the vertical curvature is greater than the horizontal (about 0.25 D). This is known as Direct or "Withthe-rule astigmatism" and is accepted as physiological in most cases. It is presumed to be due to constant pressure of upper eyelid. As the age advances, it tends to increase to a very slight extent, but in older age it tends to disappear or even reverse itself to an "Inverse astigmatism" or "Against-the rule astigmatism" wherein the vertical curvature is more than the horizontal curvature.

For over a century, it has been recognised that cataract incisions influences astigmatism. Only in the past 15 years, the cataract surgeons have mounted serious investigations armed at measuring and minimizing astigmatism induced by cataract surgery [3]. Corneal astigmatism being commonly associated with manual small incision cataract surgery postoperatively, planning out the modifications of the surgical intervention especially the incision according to the state of astigmatism present pre-operatively is necessary to reduce or correct existing refractive error or astigmatism [4]. Thus control of post-operative astigmatism is key to good postoperative vision without spectacles [5].

Pre-existing astigmatism is present in over $60 \%$ of all patients scheduled for cataract surgery [6]. Girard and Hoffman were the first to call the posterior incision "scleral tunnel incision" and were the first to practice entry from a slightly corneal location [7]. Recent sutureless unlike ECCE, which required number of sclero-corneal stitches and selfsealing scleral tunnel small incisions have imparted not only self-sealability but also astigmatic neutrality [8,9]. Though, for any leaking incision, 10-0 nylon or vicryl suture can be used to give horizontal single suture [10]. In recent times, surgeons prefer to start the incision from the vascular region preferably on the sclera due to its stability and rapid healing. Choice of the incision site is made taking into consideration about the rapid healing of the wound and its potential to correct astigmatism. Along with the site, healing also varies on whether the conjunctival flap is fornix based or limbal based and presence of sutures [11]

The scleral flap incisions has 3 dimensions-depth (thickness of the flap), width (the perpendicular distance from the scleral groove to the line of entry into anterior chamber), length (the distance between the lengths of the incision measured along the contour of the incision). Scleral incision can be superotemporal or superior. Superotemporal scleral incision (STI) in comparison to superior incision, gives greater access to the incisions, better visibility of intraocular structures, lesser endothelial damage due to location of the incision farthest from the visual axis, advantageous in terms of astigmatism since it induces with-the-rule astigmatism in most cases and it is very helpful for elderly patients developing cataract since they generally have against-the -rule (ATR) astigmatism pre-operatively and absence of postoperative ptosis by avoiding superior rectus bridle suture
[12]. Intraoperatively, superotemporal incision gives greater access to the incision than working over the brow and natural drainage of the fluid due to the presence of lateral central angle just beneath the incision. Superotemporal incision also neutralizes the forces of gravity and eyelid drag on the incision unlike superior incision. Whereas superior scleral incision (SI) is advantageous in patients with with-the-rule (WTR) astigmatism present preoperatively. Whereever the incision is, scleral, corneal or anterior or posterior limbal, incision creates a tissue gape which causes flattening along the meridian of incision and steepening in the meridian 90 degree away [13]. Suture produces local tissue compression, resulting in peripheral flattening and central steepening along the meridian of incision and flattening 90 degree away [14]. The size, shape and location of external incision influence the induced astigmatism after cataract surgery.

In this study, we will be concentrating on incidence, amount and type of post-operative astigmatism and astigmatism shift in both superior and superotemporal scleral incision in MSICS and a comparison among them in two kinds of incisions.

\section{Materials and methods}

This is a hospital based prospective comparative study done on 100 patients with age related senile cataract attending out-patient department of Ophthalmology at Jagannath Gupta Institute of Medical Sciences, Kolkata between August, 2020 to July, 2021. All the patients underwent manual small incision cataract surgery (MSICS), half of them with superior scleral incision and rest half with superotemporal incision. All were evaluated and managed in the same hospital and they underwent post-operative follow up as outpatient in the same.

\section{Inclusion criteria}

1. Age related senile cataract.

2. No associated ocular disorders like previous ocular surgeries, history of trauma, glaucoma etc.

3. No associated systemic disorders.

4. Patients who were posted for manual small incision cataract surgery.

\section{Exclusion criteria}

1. Age below 40 and above 90 years.

2. Corneal surface irregularities.

3. Associated ocular disorders.

4. Combined surgical procedures at the time of surgery like trabeculectomy, pterygium excision.

5. Previous ocular surgeries.

6. With systemic connective tissue disorders.

7. Inability to give informed consent. 


\section{Congenital and developmental cataract.}

Pre-operatively detailed history regarding ocular and systemic complains if any along with drug and family history were taken followed by general physical and systemic examination. Visual acuity was recorded for both distance and near, both unaided and aided (if applicable) along with detailed anterior segment examination under slit lamp biomicroscopy. Posterior segment was examined with both direct and indirect ophthalmoscopy along with intraocular pressure with Schiotz tonometer and lacrimal syringing before posting for surgery. Necessary investigations were done, physician fitness obtained and the patients were started on oral and topical antibiotics one day prior to surgery. Xylocaine test dose was given one day before surgery too.

All 100 cases underwent manual small incision cataract surgery with PCIOL implantation. Among them, 50 underwent MSICS with superior scleral incision whereas rest 50 with superotemporal scleral incision. Pre-operative mydriasis was achieved using tropicamide $0.5 \%$ and phenylephrine $5 \%$ eyedrops along with flurbiprofen $0.03 \%$ eyedrop.

After preparing the eye for surgery, peribulbar anaesthesia was given. In half of the patients, a straight scleral incision of about $6.5 \mathrm{~mm}$ was placed $2 \mathrm{~mm}$ behind the limbus using 11 no. B.P. blade. Dissection of sclerocorneal tunnel was done by crescent blade upto $1 \mathrm{~mm}$ inside the cornea. Whereas, in remaining 50 patients, fornix based conjunctival flap was taken from 12 o'clock to 3 o'clock, following which $6.5 \mathrm{~mm}$ scleral straight incision was placed in the same region around 1-1.5 mm posterior to limbus and sideport was made 3 o'clock hours away from the main port. Remaining steps are done similarly in all 100 cases according to conventional MSICS procedure. Intraoperative complications if any were managed accordingly.

A detailed post-operative examination was done on $1^{\text {st }}$ day, $7^{\text {th }}$ day, $2^{\text {nd }}$ week and $4^{\text {th }}$ week. Cases with 70-110 degree axes are considered as WTR astigmatism, cases with 160-20 degree were considered ATR astigmatism and other than these axes were excluded from study.

\section{Results}

A randomized comparative study of astigmatism at postoperative follow ups following superior (SI) or superotemporal scleral incision (STI) in manual small incision cataract surgery in total 100 patients with 50 each with each incision at Jagannath Gupta Medical College and Hospital, Budge Budge, Kolkata was done at a period of one year (Table 1).

\begin{tabular}{|c|c|c|c|}
\hline Table 1: Sex distribution. & \multicolumn{3}{|c|}{} \\
\hline Sex & SI & STI & $\%$ \\
\hline Male & 24 & 27 & $51 \%$ \\
\hline Female & 26 & 23 & $49 \%$ \\
\hline Total & 50 & 50 & $100 \%$ \\
\hline
\end{tabular}

In the present study it is seen that in superior scleral incision group $47 \%$ are males while in superotemporal scleral incision group 53\% are male and rest $47 \%$ are females (Graph 1).

In this study, we can see that the majority of patients who underwent MSICS were in age group of 51-70 years (59\%). The mean age group with superior incision and superotemporal incision are 64.50 years and 62.86 years respectively (Table 2).

In the present study, it was found that $68 \%$ of the patients of both groups who underwent MSICS had visual acuity less than $6 / 60$, whereas rest $32 \%$ had visual acuity more than 6/60 (Graph 2).

In this study, it is seen that $18(36 \%)$ patients who had WTR astigmatism underwent SI and rest 19 (38\%) underwent STI, whereas 21 (42\%) patients of those who had ATR astigmatism underwent SI and rest 44\% underwent STI (Table 3, Graph 3).

In this study, it is seen that out of 18 patients with
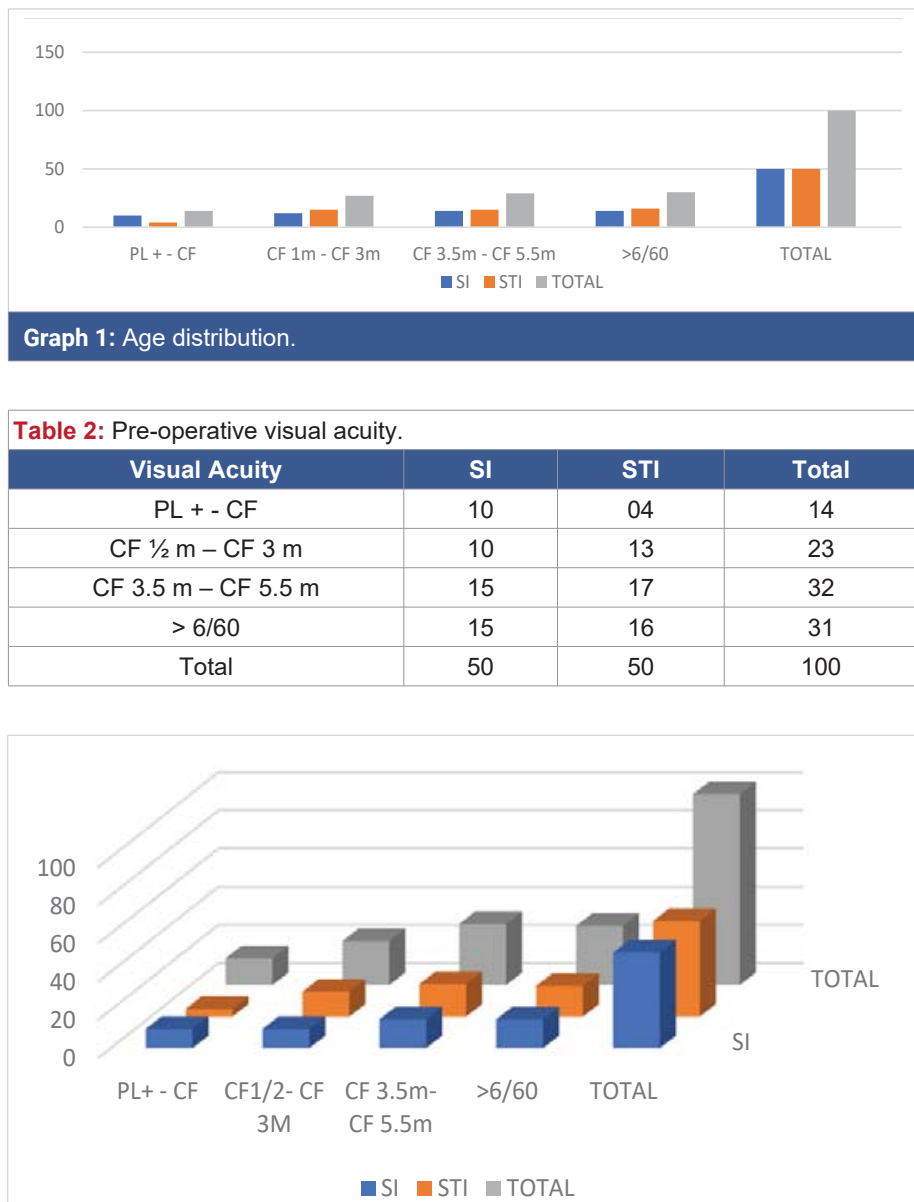

Graph 2: Pre-operative visual acuity

Table 3: Pre-operative astigmatism.

\begin{tabular}{|c|c|c|c|}
\hline Type of astigmatism & SI & STI & Total \\
\hline WTR & $18(36 \%)$ & $19(38 \%)$ & $37(37 \%)$ \\
\hline ATR & $21(42 \%)$ & $22(44 \%)$ & $43(43 \%)$ \\
\hline NA & $11(22 \%)$ & $9(18 \%)$ & $20(20 \%)$ \\
\hline
\end{tabular}




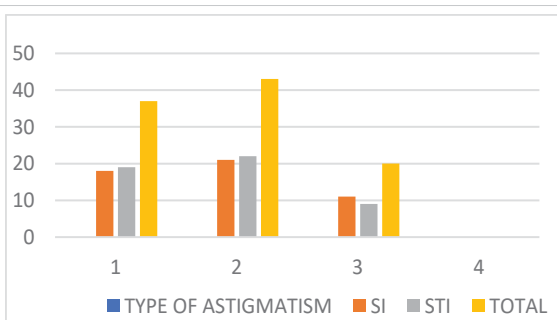

Graph 3: Pre-operative astigmatism.

preoperative WTR astigmatism who underwent SI, $13(72.22 \%)$ had increased while 2 (11.11\%) had decreased and only $3(16.67 \%)$ had same amount of WTR astigmatism $1^{\text {st }}$ postoperative day. On $7^{\text {th }}$ day, only 7 (55.56\%) patients had increased while 9 (50\%) had decresased WTR astigmatism. By $2^{\text {nd }}$ and $4^{\text {th }}$ week postoperatively, number of patients with increased WTR astigmatism remained almost same whereas, number of patients with decreased astigmatism increased drastically in comparison to the $1^{\text {st }}$ from $2(11.11 \%)$ to $9(50 \%)$. On other hand, STI group shows that on $1^{\text {st }}$ post-operative day, out of 19 patients who had WTR astigmatism pre-operatively, $10(52.63 \%)$ had increased but 6 (31.58\%) had decreased amount of astigmatism while for only 3 patients no variation was there. On $7^{\text {th }}$ post-operative day, it is seen that the number of patients with increased astigmatism increased slightly from 10 to 13 , with a gradual decrease in the number of patients with reduced astigmatism from 6 to 4 . By $2^{\text {nd }}$ and $4^{\text {th }}$ week, the number of patients with increased and reduced WTR astigmatism became constant to 14 (73.68\%) and 4 (21.05\%) respectively. Thus it is seen that in SI group the number of patients with postoperative decreased pre-existing WTR astigmatism was more than that of the STI group (Tables 4-6, Graphs 4-6).

This study shows that out of 21 patients who had ATR astigmatism pre-operatively and underwent superior incision, $18(85.71 \%)$ patients had increased ATR astigmatism on $1^{\text {st }}$ post-operative day, while only $1(0.21 \%)$ had decreased astigmatism. On $7^{\text {th }}$ day, these numbers changed to $13(61.9 \%)$ with increased astigmatism and 04 (19.04\%) with reduced astigmatism. By $2^{\text {nd }}$ and $4^{\text {th }}$ post-operative week, it is seen that there was increased amount of astigmatism with 12 (57.14\%) and $14(66.67 \%)$ patients respectively whereas the number of patients with reduced amount of ATR astigmatism was only $05(23.81 \%)$ and $4(19.05 \%)$ respectively, However, with STI group, this trend is opposite with only 10 out of $22(45.45 \%)$ had increased ATR astigmatism on $1^{\text {st }}$ post-operative day which decreased to only $5(22.73 \%)$ and $3(13.64 \%)$ by $2^{\text {nd }}$ and $4^{\text {th }}$ week. Whereas, the number of patients with reduced astigmatism was higher than that of SI group which was only with 11 on $1^{\text {st }}$ post-operative day and thereafter it increased drastically to $15(68.18 \%)$ and $18(81.82 \%)$ on $2^{\text {nd }}$ and $4^{\text {th }}$ postoperative week respectively. Thus it is seen, that superotemporal incision caused decreased ATR astigmatism in most cases in comparison superior incision which showed increased astigmatism among the most (Table 7).
Table 4: Pre and Post-operative astigmatism in superior and superotemporal scleral incision.

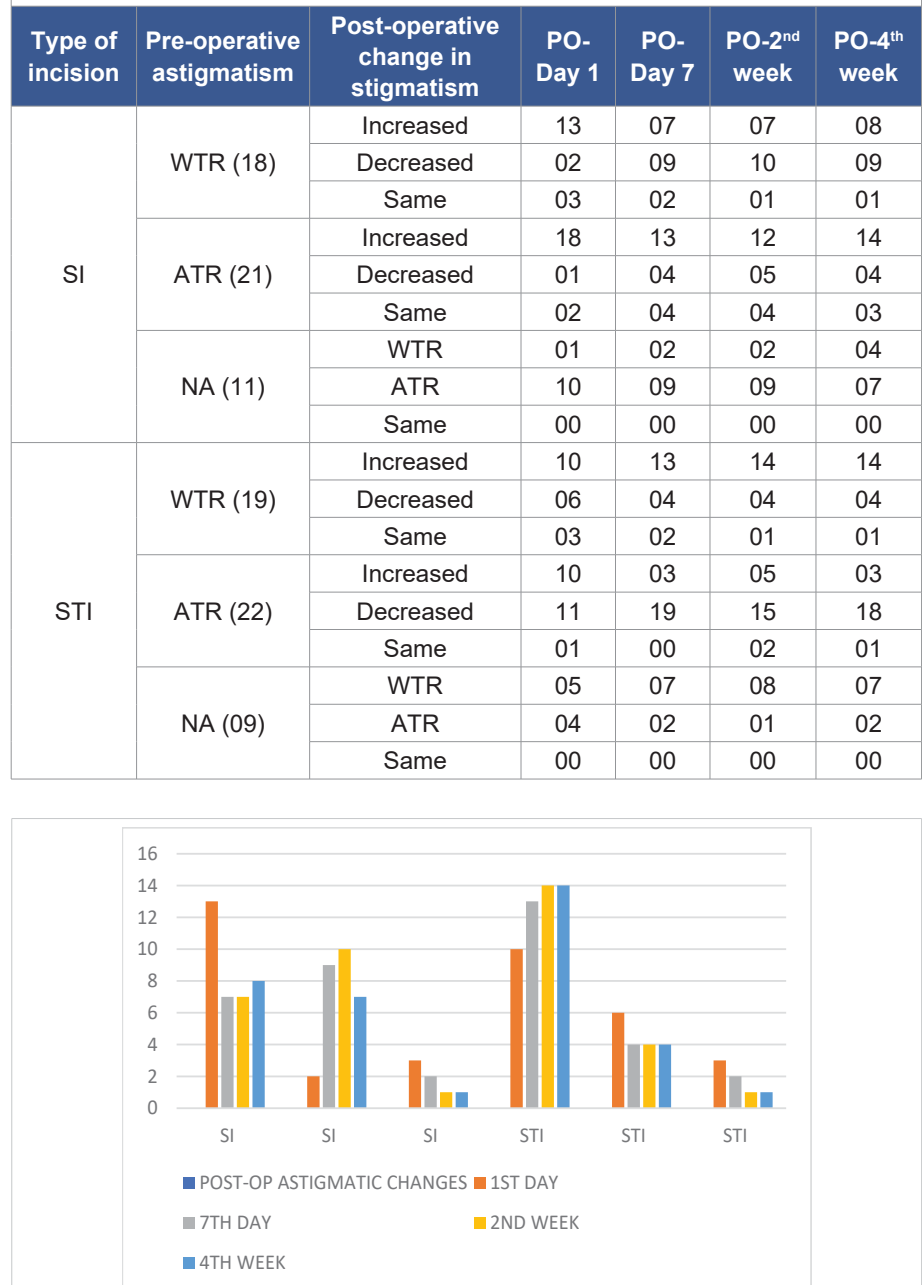

Graph 4: Post-operative astigmatic changes in patients with pre-operative WTR astigmatism in superior and superotemporal incision.

Table 5: Post-operative astigmatic changes in patients with pre-operative WTR astigmatism in superior and superotemporal incision.

\begin{tabular}{|c|c|c|c|c|c|}
\hline $\begin{array}{c}\text { Type of incision } \\
\text { (no. of cases) }\end{array}$ & $\begin{array}{c}\text { Post-op astigmatic } \\
\text { changes }\end{array}$ & Day-1 & Day-7 & $2^{\text {nd }}$ week & $\mathbf{4}^{\text {th }}$ week \\
\hline \multirow{2}{*}{ SI } & Increased & 13 & 07 & 07 & 08 \\
\cline { 2 - 6 } & Decreased & 02 & 09 & 10 & 09 \\
\cline { 2 - 6 } & Same & 03 & 02 & 01 & 01 \\
\hline \multirow{2}{*}{ STI } & Increased & 10 & 13 & 14 & 14 \\
\hline$(19)$ & Decreased & 06 & 04 & 04 & 04 \\
\hline Chi Square Test $\left(x^{2}\right)$ & Same & 03 & 02 & 01 & 01 \\
\hline$p$ value & & 9.8645 & 0.8251 & 2.9742 & 3.2637 \\
\hline
\end{tabular}

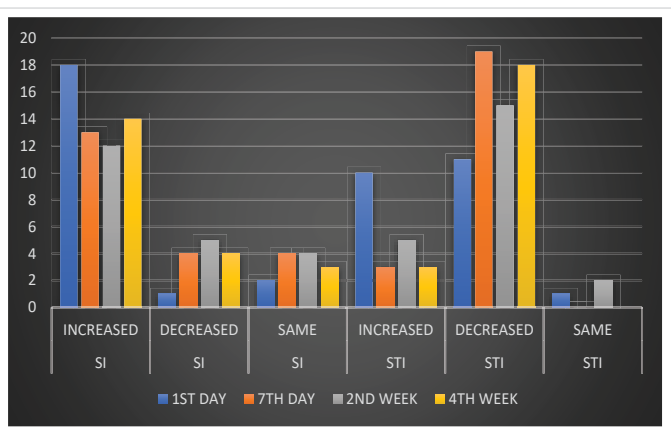

Graph 5: Post operative astigmatic changes in patients with preoperative ATR astigmatism in superior and superotemporal incision. 
Table 6: Post-operative astigmatic changes in patients with pre-operative ATR astigmatism in superior and superotemporal incision.

\begin{tabular}{|c|c|c|c|c|c|}
\hline \multirow{2}{*}{ Type of incision } & $\begin{array}{c}\text { Post-operative } \\
\text { astigmatic changes }\end{array}$ & $\mathbf{1}^{\text {st }}$ Day & $\mathbf{7}^{\text {th }}$ Day & $\mathbf{2}^{\text {nd }}$ week & $\mathbf{4}^{\text {th }}$ week \\
\hline \multirow{3}{*}{ SI (21) } & Increased & 18 & 13 & 12 & 14 \\
\cline { 2 - 6 } & Decreased & 01 & 04 & 05 & 04 \\
\cline { 2 - 6 } & Same & 02 & 04 & 04 & 03 \\
\hline \multirow{2}{*}{ STI (22) } & Increased & 10 & 03 & 05 & 03 \\
\cline { 2 - 6 } & Decreased & 11 & 19 & 15 & 18 \\
\hline ChiSquare Test & Same & 01 & 00 & 02 & 01 \\
\hline$p$ value & & 11.8797 & 11.0506 & 3.5484 & 1.9997 \\
\hline
\end{tabular}

\section{Chart Title}

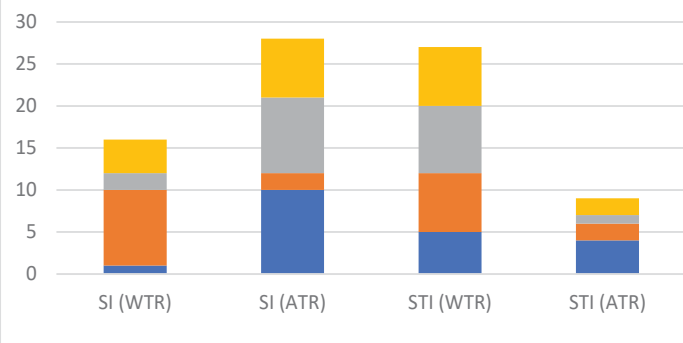

—1ST DAY —7TH DAY —2ND WEEK —4TH WEEK

Graph 6: Postoperative astigmatic changes with no astigmatism preoperatively in superior and superotemporal incision.

Table 7: Post-operative astigmatic changes in patients with NO ASTIGMATISM preoperatively in superior and superotemporal incision.

\begin{tabular}{|c|c|c|c|c|c|}
\hline \multirow{2}{*}{ Type of incision } & $\begin{array}{c}\text { Post-operative } \\
\text { astigmatic change }\end{array}$ & $\mathbf{1}^{\text {st }}$ Day & $\mathbf{7}^{\text {th }}$ Day & $2^{\text {nd }}$ week & $4^{\text {th }}$ week \\
\hline SI & WTR & 01 & 09 & 02 & 04 \\
\cline { 2 - 6 }$(11)$ & ATR & 10 & 02 & 09 & 07 \\
\hline STI & WTR & 05 & 07 & 08 & 07 \\
\hline (09) & ATR & 04 & 02 & 01 & 02 \\
\hline \multirow{2}{*}{ Fischer exact test } & & $\begin{array}{c}0.0498 \\
(<0.05)\end{array}$ & $\begin{array}{c}1.000 \\
(>0.05)\end{array}$ & $\begin{array}{c}0.0055 \\
(<0.05)\end{array}$ & $\begin{array}{c}0.0923 \\
(>0.05)\end{array}$ \\
\hline
\end{tabular}

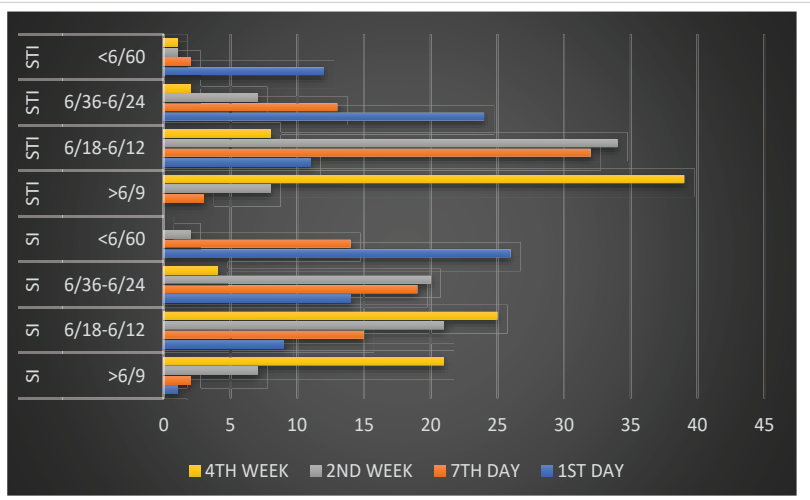

Graph 7: Comparison of post-operative visual acuity in SI and STI.

Table 8: Comparison of post-operative visual acuity in SI and STI group.

\begin{tabular}{|c|c|c|c|c|c|}
\hline $\begin{array}{c}\text { Type of } \\
\text { incision }\end{array}$ & $\begin{array}{c}\text { Visual } \\
\text { Acuity }\end{array}$ & $\mathbf{1}^{\text {st }}$ Day & $\mathbf{7}^{\text {th }}$ Day & $\mathbf{2}^{\text {nd }}$ week & $\mathbf{4}^{\text {th }}$ week \\
\hline \multirow{5}{*}{} & $>6 / 9$ & 1 & 2 & 7 & 21 \\
\cline { 2 - 7 } & $6 / 18-6 / 12$ & 9 & 15 & 21 & 25 \\
\cline { 2 - 6 } & $6 / 36-6 / 24$ & 14 & 19 & 20 & 4 \\
\cline { 2 - 7 } & $<6 / 60$ & 26 & 14 & 2 & 0 \\
\hline \multirow{3}{*}{ SI } & $>6 / 9$ & 0 & 3 & 8 & 39 \\
\hline \multirow{3}{*}{ STI } & $6 / 18-6 / 12$ & 11 & 32 & 34 & 8 \\
\cline { 2 - 7 } & $6 / 36-6 / 24$ & 24 & 13 & 7 & 2 \\
\cline { 2 - 7 } & $<6 / 60$ & 12 & 02 & 1 & 1 \\
\hline
\end{tabular}

In the present study, it is seen that total $19(19 \%)$ patients were not having any astigmatism preoperatively, among which 11underwent superior incision and rest 9 underwent superotemporal incision. In SI group, only 1 patient developed WTR astigmatism and 10 developed ATR astigmatism on $1^{\text {st }}$ post-operative day whereas, in STI group number of patients who developed WTR and ATR astigmatism on $1^{\text {st }}$ postoperative day were 5 and 4 respectively.

On $7^{\text {th }}$ day, 9 and 2 patients of SI and 7 and 2 patients of STI group developed WTR and ATR astigmatism respectively. By $2^{\text {nd }}$ and $4^{\text {th }}$ week, 2 and 4 patients from SI group and 8 and 7 from STI group developed WTR astigmatism respectively and 9 and 7 patients from SI group and 1 and 2 from STI group developed ATR astigmatism respectively.

In this study, we can see that on $1^{\text {st }}$ post-operative day, most number of patients, 26 (52\%) who underwent SI fell in the group of visual acuity less than 6/60, whereas of STI group, most of them, $24(48 \%)$ fall in the group of visual acuity within the range of $6 / 36-6 / 24$. However, on $7^{\text {th }}$ day, in SI group, 19 (38\%) had visual acuity ranging from 6/366/24, followed by 15 (30\%) with 6/18-6/12 vision and 14 (28\%) with less than 6/60 vision. Whereas, in STI group, most of them, $32(64 \%)$ had a vision of $6 / 18-6 / 12$ on $7^{\text {th }}$ postoperative day, followed by only $13(26 \%)$ and $2(4 \%)$ patients with vision of 6/36-6/24 and less than 6/60 respectively. By $2^{\text {nd }}$ and $4^{\text {th }}$ post-operative week, only $7(14 \%)$ and $21(42 \%)$ of SI group had a vision better than $6 / 9$ respectively followed by $21(42 \%)$ and $25(50 \%)$ with vision 6/18-6/12. On the other hand, STI group has more number of patients with vision more than $6 / 9,39(78 \%)$ at the end of $4^{\text {th }}$ week though this number was more within the range of 6/18-6/12 at $2^{\text {nd }}$ week, $34(68 \%)$ and it was more than the same for SI group at the same time period. Thus, it is seen that by the end of 1 month, more number of patients with Superotemporal incision had a vision of more than $6 / 9$ than that who underwent superior incision. It is also seen that within 7 days, number of patients with vision $6 / 18-6 / 12$ is reaching high to $32(64 \%)$ with STI group in contrast to only $15(30 \%)$ with SI group, which proves that superotemporal incision gives an early and better bisual outcome post-operatively (Table 8, Graph 7) .

\section{Discussion}

Various theories have been put forward to explain the factors responsible for surgically induced astigmatism-

1. Astigmatism is proportional to the cube of the length of the incision. (Gill and Sanders).

2. Astigmatism is inversely related to the distance from the limbus. (Jaffey, Samuel Mesket).

3. Incisional funnel- imaginary pair of curved lines diverging outwards from limbus. Incisions made within this funnel will be astigmatic equivalent. (Paul Koch). 
Thus curvilinear incision parallel to limbus being out of this funnel is unstable whereas straight incisions are less out of this funnel and thus they are more stable than curvilinear incision which creates a potential for wound slide and ATR drift in astigmatism in case of curvilinear incision. Frown incision falls totally within this funnel with its margin moving away from the cornea thus making it a stable incision and stabilizes the astigmatism to a greater range [15]. But in both frown and Chevron inverted $V$ incision, it is difficult to convert the incision to ECCE in case of emergency [16].

The simple rule to follow is that where ever the incision is made, that area will flatten and where ever sutures are applied, that area will flatten. An incision on the cornea or sclera creates a tissue gape; this gape causes corneal flattening along the meridian of incision and steepening in the meridian 90 degrees away [17]. Therefore, size, shape, location, axis, direction of the incision along with its distance from the limbus and the optical centre in total influences the degree of astigmatism post-operatively. When preoperative astigmatism is low , the ideal small incision should be straight and possibly in the temporal region which is done to retain the preoperative sphericity. A frown incision $3 \mathrm{~mm}$ behind the cornea can also achieve this goal by being within the astigmatically neutral funnel. When preoperative astigmatism exceeds 4D, the implant power has to be modified to counter the effect of coupling [18].

Superotemporal incision also provide other advatages like better wound strength due to minimal separational force of lid pressure and gravity, preservation of functioning filter bleb in previous glaucoma surgery. It is preferred in deeply seated eyes and eyes with coloboma iris. This incision site also causes less central corneal endothelial loss [19].

Thus an obvious approach is to reduce the change of astigmatic shift by an incision which is small, away from the cornea, either straight or frown shaped to stay within astigmatically neutral zone, multiplanar and one that can be left unsutured. Also wounds with a square configuration are considered desirable [20].

In this recent study, it is seen that the average preoperative astigmatism in both group (SI and STI) is nearly $0.80 \mathrm{D}$ and is present in around $90 \%$ cases with WTR in $37 \%$

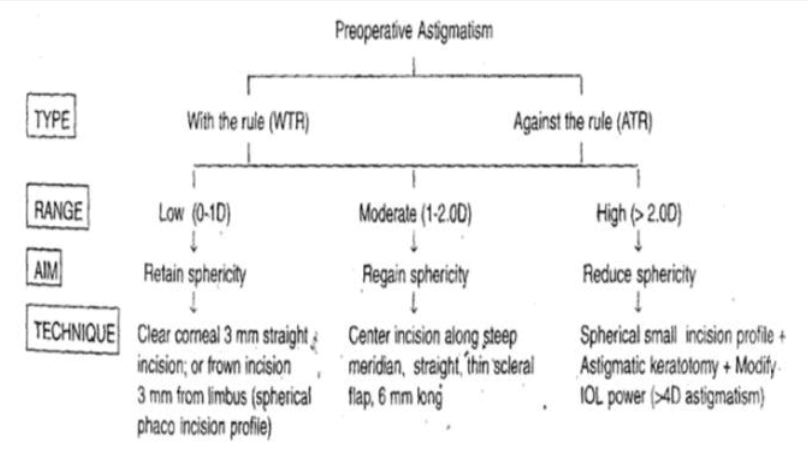

and ATR in $43 \%$ cases. There is a significant difference in the amount of astigmatism in both the groups which thereafter gradually reduced significantly by $4^{\text {th }}$ week. The mean postoperative astigmatism is higher with group with superior incision the an superotemporal incision group by first one week postoperatively. Even after postoperative 2 weeks, the superior incision group has higher astigmatism than that of superotemporal group with a significant difference. However, after 4 weeks, not much reduction is seen in both the groups which shows that most of the stabilization of astigmatism occurred by $4^{\text {th }}$ week.

Visual acuity didn't improve significantly on $1^{\text {st }}$ day in both groups whereas by 1 week, visual acuity improved in more number of cases in superotemporal incision than the other group which by $4^{\text {th }}$ week the difference increased drastically with more satisfactory improvement with superotemporal incision.

In superotemporal incision group, minimal WTR astigmatism and early rehabilitation of visual recovery could be due to location of the incision away from the visual axis and steepening of the vertical meridian unlike superior incision. Superotemporal incision causes minimal WTR astigmatism whereas SI group had majority of ATR astigmatism. Besides, superotemporal incision can neutralize ATR astigmatism which is advantageous since most elderly cataract patients had preoperative ATR astigmatism.

Besides, the average astigmatism in SI group is higher and majority of them being ATR type than that of STI group in which majority of them are having WTR astigmatism.

Thus, this study concludes that superotemporal incision is advantageous in comparison to superior incision in MSICS with respect to betterment of preoperative astigmatism along with significant reduction of chances of postoperative astigmatism and better visual acuity.

\section{Conclusion}

Post-operative astigmatism, being a common complication to cataract surgery, can be reduced or avoided with modification of location, sutureless, self-healing incision. Placement of incision temporally or superotemporally is one modification to minimise the high pre-existing ATR astigmatism, thereby improving the visual outcome.

This study suggests that sutureless superotemporal scleral incision produces less post-operative astigmatism than superior scleral incision.

It is seen, that superotemporal incision causes with-therule astigmatism in most of the cases postoperatively along with a capability of neutralizing against-the-rule astigmatism which will be present in majority of elderly patients with cataract, whereas superior scleral incision causes against-therule astigmatism in the most. 
This study also supports that there will be better and early uncorrected visual acuity among those who underwent superotemporal incision than that of superior incision.

Thus, superotemporal incision shows minimal post cataract surgery complications in terms of astigmatism, with early and better visual outcome in comparison to superior incision.

\section{References}

1. Astigmatism; David Abrahams: Duke Elder's Practice of Refraction $10^{\text {th }}$ edition, BI Churchill Livingstone; New Delhi: 65-71.

2. Morlet N, Minassian D, Dart J. Astigmatism and the analysis of its surgical correction. Br J Ophthalmol. 2001; 85: 1127-1138.

PubMed: https://www.ncbi.nlm.nih.gov/pmc/articles/PMC1724117/

3. Richard LL, Douglas DK, Robert HO, Wang L. Control of Astigmatism in Cataract Patients, In: Roger F Steinert. Cataract Surgery Techniques Complication and Managaement. $2^{\text {nd }}$ Edition. Philadelphia. Saunders; 2004; 253-266.

4. Rathore MK. Temporal Tunnel Incision in SICS, In: Kamaljeet Singh Small Incision Cataract Surgery (phaco manual). $1^{\text {st }}$ Edition. New Delhi. Jaypee Brothers. 2002; 136-139.

5. Akuda J, Kaneda S, Hatta S, Matsuura K. Controlling Astigmatism in Cataract Surgery requiring relatively large self-sealing incisions. J Cataract Refract Surg. 2000; 26: 1650-1659.

PubMed: https://pubmed.ncbi.nlm.nih.gov/11084275/

6. Gills JP. Reducing Pre-existing Astigmatism with limbal relaxing incisions In: Sunita Agarwal, I H Fine. Phacoemulsification, Laser cataract surgery and foldable IOLs. $1^{\text {st }}$ Edition. New Delhi. Jaypee Brothers. 1998; 393-400.

7. Girard LJ, Hoffman RF. Scleral tunnel to prevent induced astigmatism. Am J Ophthalmol. 1984; 94: 450-456.

8. Oshika T, Sugita G, Tanabe T, Tomidokoro A, Amano S. Regular and irregular astigmatism after superior vs temporal scleral incision cataract surgery. Ophthalmology. 2000; 107: 2049-2053.

PubMed: https://pubmed.ncbi.nlm.nih.gov/11054330/

9. Sachdev MS, Mishra P, Thanikachalam S. The Manual small incision:
Surgical Aspect-1, In: Kamaljeet Singh. Small Incision Cataract Surgery (phaco manual). $1^{\text {st }}$ Edition. New Delhi. Jaypee Brothers. 2002; 75-83.

10. Tabin G, Ruit S. Small Incision Sutureless Temporal Approach Extracapsular Cataract Surgery. Ashok Garg. Clinical Practice in Small Incision Cataract Surgery (phaco manual). $1^{\text {st }}$ Edition. New Delhi. Jaypee Brothers. 2004; 399-411.

11. Jaffe NS, Jaffe MS, Jaffe GF. Anaesthesia, wound healing, sutures, and needles, In: Cataract Surgery and its complications. $6^{\text {th }}$ Edition. St. Louis. Missouri. Mosby. 1997; 18-47.

12. Kapoor S, Incisions, In: IH Fine, Amar Agarwal, Sunita Agarwal and Keiki Mehta. Phacoemulsification, Laser Cataract Surgery and Foldable IOLs. $1^{\text {st }}$ Edition. New Delhi: Jaypee Brothers. 1998; 67-80.

13. Agarwal A. Corneal Topography in Cataract Surgery, In: I H Fine, Amar Agarwal, Sunita Agarwal, Keiki Mehta. Phacoemulsification, Laser Cataract Surgery and Foldable IOL. $1^{\text {st }}$ Edition. New Delhi. Jaypee Brothers. 1998; 24-33.

14. Jaffe NS, Clayman HM. The pathophysiology of corneal astigmatism after cataract extraction. Ophthalmology. 1975; 79: 915-930.

15. Fine $\mathrm{IH}$. Architecture and construction of self-sealing incision or cataract surgery. J Cataract Refract Surg. 1991; 17: 672-673. PubMed: https://pubmed.ncbi.nlm.nih.gov/1955984/

16. Pallin SL. Chevron incision of cataract surgery. J Cataract Refract Surg. 1990; 16: 779-781.

PubMed: https://pubmed.ncbi.nlm.nih.gov/2258822/

17. Masket S. Temporal incision for astigmatic control in secondary implantation. J cataract Refract Surg. 1986; 12: 179-181. PubMed: https://pubmed.ncbi.nlm.nih.gov/3517298/

18. Sachdeva MS, Venkatesh P. The Manual Small Incision: Surgical Aspect-2, In: Kamaljeet Singh, $1^{\text {st }}$ Edition. New Delhi. Jaypee Brothers. 202: 84-85.

19. Hoffer KJ. Cell Loss with Temporal and Superior Incisions. J Cataract Refract Surg. 1994; 20: 308.

PubMed: https://pubmed.ncbi.nlm.nih.gov/8064622/

20. Axtl JC, McCaffery JC. Reduction of postoperative against-the- rule astigmatism by lateral incision technique. J Cataract Refract Surg.1993; 19: 308-306.

PubMed: https://pubmed.ncbi.nlm.nih.gov/8501634/ 